\title{
KARAKTERISTIK AKAD PEMBIAYAAN AL-QARDH SEBAGAI AKAD TABARRU'
}

\author{
Farid Budiman \\ budiman212@yahoo.co.id \\ Pengamat Hukum
}

\begin{abstract}
Basically, the contract tabarru' is give (giving something) or lend (lending something). If the 'akad' is lent something, the object can be money lending (lending) or service (lending yourself). Though the parties do good must not profit from the transaction tabarru', he still could ask the other party receives a kindness to reimburse -costs incurred for the transaction tabarru 'is, but he still should not be taking advantage although a small amount of the transaction tabarru'.
\end{abstract}

Keywords: akad, qardh, tabarru'.

\begin{abstract}
Abstrak
Pada dasarnya, akad tabarru' ini adalah memberikan sesuatu (giving something) atau meminjamkan sesuatu (lending something). Apabila akadnya adalah meminjamkan sesuatu, objek pinjamannya dapat berupa uang (lending) atau jasa kita (lending yourself).Meskipun pihak yang berbuat kebaikan tidak boleh mengambil keuntungan dari transaksi tabarru',dia masih bisa meminta kepada pihak lain yang menerima kebaikannya untuk sekedar mengganti biaya-biaya yang telah dikeluarkan untuk transaksi tabarru'tersebut, namun ia tetap tidak boleh mengambil keuntungan meskipun dalam jumlah sedikit dari transaksi tabarru’.
\end{abstract}

Kata kunci: akad, qardh, tabarru' 


\section{Pendahuluan}

Bank syariah didalam menghimpun dan menyalurkan dana dalam bentuk pembiayaan dikenal ada 2 (dua) jenis akad, yaitu akad tabarru' dan tijarah. Pembahasan kali ini akan membahas salah satu jenis akad tersebut, yakni jenis akad tabarru'.Sebelum masuk dalam pembahasan terbelih dahulu perlunya memahami pengertian dari akad tabarru'.Menurut kamus, akad tabarru' adalah akad pemilikan sesuatu tanpa 'iwadl/penukaran, seperti : hibah, shadaqah, wasiat dan wakaf. Tabarru' merupakan sikap atau perbuatan mencari berkah dari suatu perbuatan. ${ }^{1}$ Kata tabarru' dalam Al-Qur'antidak ditemukan. Akan tetapi, tabarru' dalam arti dana kebajikan dari kata al-birr: "kebajikan" dapat ditemukan dalam Al-Qur'an :2

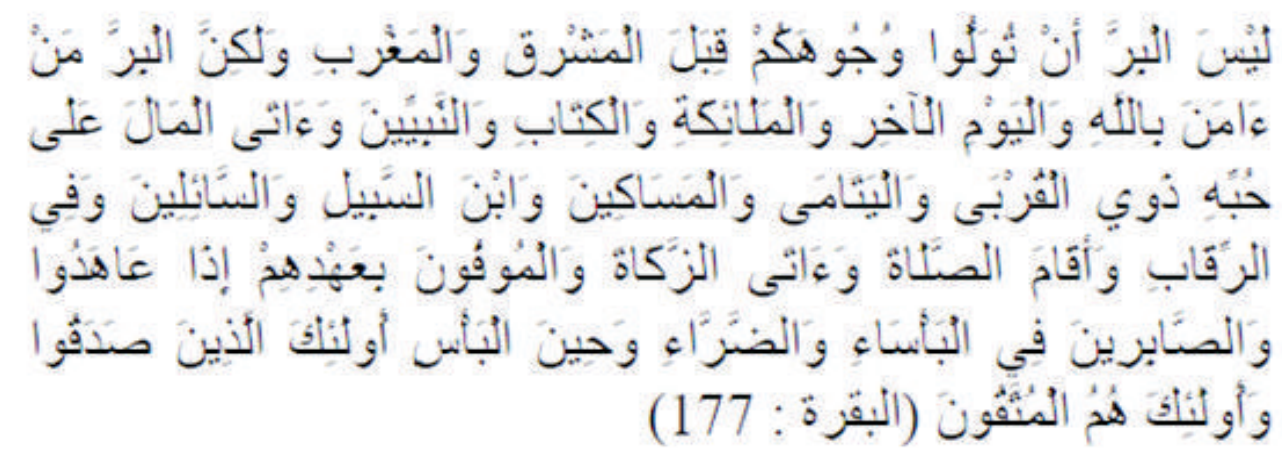

Artinya : Bukanlah menghadapkan wajahmu ke arah timur dan barat itu suatu kebajikan, akan tetapi sesungguhnya kebajikan itu ialah beriman kepada Allah, hari kemudian, malaikat-malaikat, kitab-kitab, nabi-nabi dan memberikan harta yang dicintainya kepada kerabatnya, anak-anak yatim, orang-orang miskin, musafir (yang memerlukan pertolongan) dan orang-orang yang meminta-minta; dan (memerdekakan) hamba sahaya, mendirikan shalat, dan menunaikan zakat; dan orang-orang yang menepati janjinya apabila ia berjanji, dan orang-orang yang sabar dalam kesempitan, penderitaan dan dalam peperangan. Mereka itulah orangorang yang benar (imannya); dan mereka itulah orang-orang yang bertakwa. (Qs. Al-Baqarah : 177). ${ }^{3}$

Tabarru' dalam makna hibah atau pemberian, dapat kita lihat dalam firman Allah :

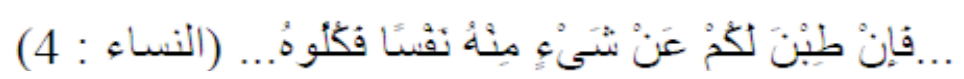

Artinya : “....Kemudian jika mereka menyerahkan kepada kamu sebagian dari maskawin itu dengan senang hati maka makanlah (ambillah) pemberian itu...” (Qs. An-Nisa : 4)

Menurut jumhur ulama ayat di atas menunjukkan (hukum) adanya anjuran untuk saling membantu antar sesama manusia.Oleh sebab itu, Islam sangat menganjurkan seseorang yang mempunyai kelebihan harta untuk menghibahkannya kepada saudara-saudaranya yang

\footnotetext{
$1 \quad$ M. Abdul Mujieb,et.al., Kamus Istilah fiqh, Jakarta: Pustaka Firdaus, 1994, h. 14.

2 Muhammad Syakir Sula, Asuransi Syari'ah (Life and General): Konsep dan system Operasional, Jakarta:Gema Insani Press, 2004, h. 35.

3 Departemen Agama RI, Al-Qur'an dan Terjemahnya, Semarang:Kumudaskoro Grafindo, 1994, h. 43.
} 
memerlukan.Mendermakan sebagian harta dengan tujuan untuk membantu seseorang dalam menghadapi kesusahan sangat dianjurkan dalam agama Islam. Penderma (mutabarri') yang ikhlas akan mendapat ganjaran pahala yang sangat besar, sebagaimana firman Allah swt dalam al-Qur'an ; ${ }^{4}$

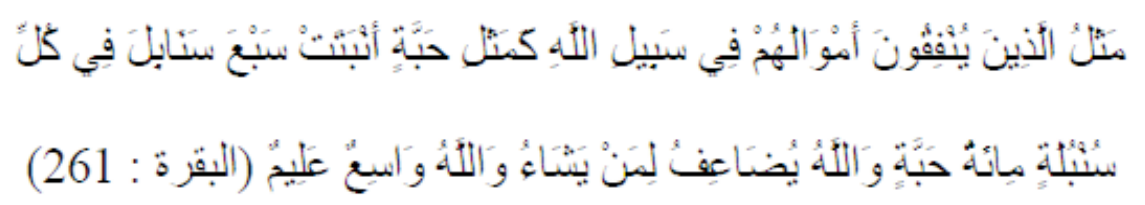

Artinya: "Perumpamaan (nafkah yang dikeluarkan oleh) orang-orang yang menafkahkan hartanya di jalan Allah adalah serupa dengansebutir benih yang menumbuhkan tujuh bulir, pada tiap-tiap bulir: seratus biji. Allah melipat gandakan (ganjaran) bagi siapa yang Dia kehendaki.Dan Allah Maha Luas (kurnia-Nya) lagi Maha Mengetahui”. (Qs. Baqarah : 261). ${ }^{5}$

Hal ini berarti dalam melakukan tabarru' tersebut tidaklah mudah, diperlukan adanya syarat-syarat didalam menjalankannya.Pemberi maupun penerima pinjaman haruslah berakal sehat, bisa berlaku dewasa artinya cukup umur dalam melakukan tindakan hukum, baligh dikenal dalam Islam, dan berkehendak tanpa ada paksaan.Syarat tersebut yang menjadi syarat untuk melakukan tabarru' (berderma).

Sehingga dalam akad-akad bank syariah jika ditinjau dari segi untuk mendapat kompensasi atau tidak mendapat kompensasi, dapat dibedakan menjadi dua jenis yaitu akad tabarru' dan akad tijarah/mu'awadah. Pertama Akad Tabarru. Akad tabarru' adalah segala macam perjanjian yang menyangkut not-for profit (transaksi nirlaba).Transaksi ini pada hakikatnya bukan transaksi bisnis untuk mencari keuntungan komersil.Akad tabarru' dilakukan dengan tujuan tolong-menolong dalam rangka berbuat kebaikan (tabarru' berasal dari kata birr dalam bahasa Arab, yang artinya kebaikan). Dalam akad tabarru', pihak yang berbuat kebaikan tersebut tidak berhak mensyaratkan imbalan apa pun kepada pihak lainnya. Imbalan dari akad tabarru' adalah dari Allah SWT., bukan dari manusia.Namun demikian, pihak yang berbuat kebaikan tersebut boleh meminta kepada counterpart-nya untuk sekedar menutupi biaya yang dikeluarkannya untuk dapat melakukan akad tabarru' tersebut.Namun ia tidak boleh sedikitpun mengambil laba dari akad tabarru' itu. ${ }^{6}$

Tetapi pada kenyataannya, penggunaan akad tabarru' sering sangat vital dalam transaksi komersil, karena akad tabarru' ini dapat digunakan untuk menjembatani atau memperlancar akad-akad tijarah. Akad tabarru' memiliki tiga bentuk, yaitu: ${ }^{7}$ a) Meminjamkan uang: qard, rahn, dan hiwalah; b) Meminjamkan jasa kita: wakalah, wadiah, dan kafalah; c) Memberikan sesuatu: hibah, hadiah, waqf, shadaqah, dll. Kedua Akad Tijarah Akad tijarah/mu'awadah adalah segala macam perjanjian yang menyangkut for profit transaction.Akad-akad ini

Ibid.h.37.

Departemen Agama RI.,Op.Cit., h. 65.

Ibid, h. 66.

Ibid, h. 66-67. 
dilakukan dengan tujuan mencari keuntungan, karena itu bersifat komersil. ${ }^{8}$ Berdasarkan tingkat kepastian dari hasil yang diperolehnya, akad tijarah dapat dibagi menjadi dua kelompok besar, yaitu: a) Natural Certainty Contract $^{9}$ Dalam NCC, kedua belah pihak saling mempertukarkan asset yang dimilikinya, karena itu objek pertukarannya (baik barang maupun jasa) pun harus ditetapkan di awal akad dengan pasti baik jumlahnya, mutunya, harganya, dan waktu penyerahannya. Jadi secara sunnatullah menawarkan return yang tetap dan pasti. Yang termasuk dalam kategori ini adalah: jual-beli (al-bai', salam dan istishna') dan sewa-menyewa (ijarah dan ijarah muntahiya bittamlik). b) Natural Uncertainty Contract ${ }^{10}$ Dalam NUC, pihakpihak yang bertransaksi saling mencampurkan asetnya (baik real assets mauun financial assets) menjadi satu kesatuan, dan kemudian menanggung resiko bersama-sama untuk mendapatkan keuntungan. Disini keuntungan dan kerugian ditanggung bersama.Karena itu, kontrak ini tidak memberikan kepastian pendapatan (return), baik dari segi jumlah maupun waktunya. Yang termasuk dalam kontak ini adalah kontrak-kontrak investasi, seperti: musyarakah (inan, wujuh, abdan, muwafadhah, dan mudharabah), muzara'ah, musaqah, dan mukhabarah.

Sebagaimana telah dijeaskan di atas yang menjadi suatu perbedaan karakteristik yang mendasar dari segi pengertian maupun contoh antara akad tabarru' dengan akad tijarah. Sehingga dapat dibedakannya produk akad pembiayaan di dalam penyaluran dananya.Sebagaimana telah dijelaskan tersebut, akad al-qardh merupakan bagian atau salah satu dari pada akad pembiayaan yang karakteristiknya termasuk dalam akad tabarru'.

Demikian juga yang dikemukakan oleh Abdul Ghofur Anshori menekankan pada prinsip-prinsip yang melandasi operasional lembaga keuangan Islam yang meliputi antara lain adalah: 1) Prinsip ta'awun (tolong menolong), yaitu prinsip saling membantu sesama dalam meningkatkan taraf hidup melalui mekanisme kerjasama ekonomi dan bisnis. Hal ini sesuai dengan anjuran Al Qur'an : “Dan tolong menolonglah kamu dalam berbuat kebajikan dan takwa serta janganlah bertolong menolong dalam berbuat keji dan permusuhan". ( QS. AlMaidah:2); 2) Prinsip tijaroh (bisnis), yaitu prinsip mencari laba dengan cara yang dibenarkan oleh syariah. Lembaga keuangan syariah harus dikelola secara professional, sehingga dapat mencapai prinsip efektif dan efisien; 3) Prinsip menghindari iktinaz (penimbunan uang), yaitu menahan uang supaya tidak berputar, sehingga tidak memberikan manfaat kepada masyarakat umum. Hal ini jelas terlarang, karena dapat menyebabkan terhentinya perekonomian; 4) Prinsip pelarangan riba, yakni menghindarkan setiap transaksi ekonomi dan bisnisnya dari unsur ribawi dengan menggantikannya melalui mekanisme kerja sama (mudharabah) dan jual beli ( al-buyu). Hal ini ditegaskan oleh Allah dalam Al Qur'an: “ Sesungguhnya orang-orang yang memakan riba tidak dapat berdiri melainkan seperti berdirinya orang yang terkena/kemasukan syetan. Yang demikian ini disebabkan mereka mengatakan bahwa jual beli itu sama dengan riba.

\footnotetext{
8 Ibid, h. 70.

Ibid, h. 72 .

10 Ibid, h. 75.
} 
Padahal Allah telah menghalalkan jual beli dan mengharamkan riba”. (QS.Al Baqarah:275); 5) Prinsip pembayaran zakat. Disamping sebagai lembaga bisnis, lembaga keuangan syariah juga menjalankan fungsinya sebagai lembaga sosial. Ia menjalankan fungsi sebagai lembaga amil yang mengelola zakat, baik yang bersumber dari dalam maupun dari luar. ${ }^{11}$

Adapun fungsi dari akad tabarru' ini adalah akad-akad untuk mencari keuntungan akhirat, karena itu bukan akad bisnis.Akad ini tidak dapat digunakan untuk tujuan-tujuan komersial. Bank syariah sebagai lembaga keuangan yang bertujuan mendapatkan laba tidak dapat mengandalkan akad-akad tabarru' untuk mendapatkan laba. Jika tujuannya mendapatkan laba, gunakanlah akad-akad yang bersifat komersial, yakni akad tijarah. Namun demikian, bukan berarti akad tabarru'sama sekali tidak dapat digunakan dalam kegiatan komersial. Bahkan pada kenyataannya, penggunaan akad tabarru' sering sangat vital dalam transaksi komersial karena akad tabarru' ini dapat digunakan untuk menjembatani atau memperlancar akad-akad tijarah.

\section{Pengertian Akad Pembiayaan Al-Qardh sebagai Akad Tabarru’}

Qardh secara etimologi adalah al-qath'u (عقط ) yang berarti potongan. ${ }^{12}$ Potongan dalam konteks akad qardh adalah potongan yang berasal dari harta orang yang memberikan uang. Sedangkan menurut istilah diartikan meminjamkan harta kepada orang lain tanpa mengharapkan imbalan.

Secara terminologis arti peminjaman adalah menyerahkan harta kepada orang yang menggunakannya untuk dikembalikan gantinya suatu saat. ${ }^{13}$ Menurut istilah para ahli fikih, al-qardh adalah memberikan suatu harta kepada orang lain untuk dikembalikan tanpa ada tambahan. Al-Qardh (pinjam meminjam) hukumnya boleh dan dibenarkan secara syariat. Tidak ada perbedaan pendapat di antara para ulama dalam hal ini. Orang yang membutuhkan boleh menyatakan ingin meminjam. Ini bukan sesuatu yang buruk, bahkan orang yang akan dipinjami justru dianjurkan (mandub). Dalil mengenai hal ini terdapat dalam Al- Quran : surat Al-Baqarah ayat $245 .{ }^{14} \mathrm{Hal}$ ini berarti sangat kental akan nuansa prinsip tolong menolong terhadap sesama manusia yang dianjurkan oleh agama Islam untuk mempunyai jiwa sosial.

Menurut Hukum Syara', para ahli fiqh mendefinisikan Qardh sebagai berikut: 1) Menurut pengikut Madzhab Hanafi, Ibn Abidin mengatakan bahwa qardh adalah suatu pinjaman atas apa yang dimiliki satu orang lalu diberikan kepada yang lain kemudian dikembalikan dalam kepunyaannya dalam baik hati; 2) Menurut Madzhab Maliki, Qardh adalah Pembayaran dari sesuatu yang berharga untuk pembayaran kembali tidak berbeda atau setimpal; 3) Menurut

\footnotetext{
11 Abdul Ghofur Anshori (I), Gadai Syariah Di Indonesia: Konsep, Implementasi dan Institusionalisasi, Yogyakarta: Gadjah Mada University Press, 2006, h. 86.

12 Al-Zuhaili.Al-fiqh al-mu'âmalat al-mâliyah, 2002, h. 89.

13 Abdullah Al-Mushlih dan Shalah Ash- Shawi, Ma La Yasa' at-Tajira Jahluhu, diterjemahkan oleh Abu Umar Basyir dengan judul Fikih Ekonomi Keuangan Islam, Jakarta: Darul Haq, 2008, h.254.

14 Musthafa Dib Al-Bugha, Fiqh Al-Mu'awadhah, diterjemahkan oleh Fakhri Ghafur dengan judul : Buku Pintar Transaksi Syariah, Jakarta: Mizan Publika, 2010, h.52.
} 
Madzhab Hanbali, Qardh adalah pembayaran uang ke seseorang siapa yang akan memperoleh manfaat dengan itu dan kembalian sesuai dengan padanannya; 4) Menurut Madzhab Syafi'i, Qardh adalah Memindahkan kepemilikan sesuatu kepada seseorang, disajikan ia perlu membayar kembali kepadanya.

Sebagaimana didalam surat Al Maidah ayat 2 juga menerangkan :“ ... Hendaklah kamu tolong menolong dalam kebaikan dan takwa dan janganlah kamu tolong menolong untuk berbuat dosa dan permusuhan”. Ayat ini menerangkan bahwa tolong menolong dalam ketaqwaan merupakan salah satu faktor penegak agama karena saling tolong menolong akan menciptakan rasa saling memiliki di antara umat sehingga akan lebih mengikat persaudaraan. ${ }^{15}$

Dilihat dari definisi diatas, maka pinjaman dapat dibagi menjadi dua bagian, yaitu pinjaman seorang hamba untuk Tuhan-Nya dan pinjaman seorang muslim untuk saudaranya. Pinjaman seorang muslim untuk Tuhannya yaitu pinjaman yang diberikan untuk membantu saudaranya tanpa mengharap kembalinya barang tersebut karena semata-mata untuk mengharapkan balasan di akhirat nanti. Hal ini mencakup infaq untuk berjihad, infaq untuk anakanak yatim, infaq untuk orang-orang jompo, dan infaq untuk orang-orang miskin. Sedangkan pinjaman seorang muslim untuk saudaranya adalah pinjaman yang sering kita lihat didalam kehidupan bermasyarakat, yang mana seseorang meminjam dari temannya karena didorong oleh adanya suatu kebutuhan dengan ketentuan mengganti/mengembalikan pinjaman tersebut.

Dari beberapa definisi diatas dapat disimpulkan bahwa, Akad Al-Qardh adalah Perikatan atau perjanjian antara kedua belah pihak, dimana pihak pertama menyediakan harta atau memberikan harta dalam arti meminjamkan kepada pihak kedua sebagai peminjam uang atau orang yang menerima harta yang dapat ditagih atau diminta kembali harta tersebut, dengan kata lain meminjamkan harta kepada orang lain yang mebutuhkan dana cepat tanpa mengharapkan imbalan.

Sebagai insan yang menjalankan syariat Islam dalam kehidupannya dimana dalam hal suatu harta benda yang dimilikinya itu semata-mata hanya titipan dari Allah dalam mendapatkan ataupun mengelola harta bendanya haruslah dengan baik untuk mencari keberkahan dari Allah. Dimana semua persoalan hidup manusia termasuk melakukan hubungan bisnis sekalipun yang menjadi dasar/prinsip didalam ekonomi syariah yang menitikberatkan persoalan-persoalan yang terjadi kembali lagi kepada Al-qur'an dan Sunnah sebagai pedoman hidup manusia.

Sistem ekonomi Islam juga dalam aktivitasnya sebagai wadah dalam menhimpun dana dan menyalurkan kembali dana dari masyarakat tersebut, guna melaksanakan prinsip-prinsip Islam untuk saling membantu dan bekerja sama didalam masyarkat agar dalam mengelola keuangan dapat pula bermanfaat bagi masyarakat lainnya yang membutuhkan. Sehingga rasa tolong-menolong dan saling memiliki dapat tumbuh didalam diri manusia tersebut.

Bank syariah selain untuk mencari keuntungan juga mempunyai misi sosial dalam produk-

15 Abd.Shomad dan Trisadini P.Usanti, “Asas-Asas Perikatan Islam dalam Akad Pembiayaan”, Yuridika, Volume 24, No.3 September-Desember, 2009, h.214. 
produknya yang disalurkan kepada masyarakat.Salah satu produk perbankan syariah yang lebih mengarah pada misi sosial ini adalah akad qardh, yang dalam fikih klasik dikategorikan dalam akad taawuniah, yaitu akad yang berdasarkan prinsip tolong menolong. ${ }^{16}$

Adapun menurut Santoso, karakteristik pembiayaan Al-qardh diantaranya adalah antara lain adalah: 1) Tidaklah diperkenankan mengambil keuntungan apapun bagi Muqridh dalam pembiayaan Al Qardh, hal tersebut sama dengan riba; 2) Pembiayaan Al-qardh menggunakan akad pinjam-meminjam, ketika barang atau uang telah diterima oleh mustaqridh maka telah barang atau uang berada dalam tanggung jawabnya dengan kewajiban untuk mengembalikan sama dengan pada saat meminjam; 3) Al-qardh biasanya dalam batas waktu tertentu, namun jika tempo pembayarannya diberikan maka akan lebih baik, karena lebih memudahkannya lagi; 4) Jika dalam bentuk barang asli yang dipinjamkan masih ada seperti semula maka harus dikembalikan dan jika telah berubah maka dikembalikan semisalnya atau seharganya; 5) Jika dalam bentuk uang maka nominal pengembalian sama dengan nominal pinjaman ${ }^{17}$

Hal tersebut merupakan karakteristik yang mendasar sehingga akad al-qardh merupakan akad tabarru', kemudian dipertegas kembali sebagaimana di dalam Fatwa DSN Nomor 19/ DSN-MUI/IV/2001 tentang Al-Qardh.Adapun hal-hal yang diatur sebagai ketentuan dasar akad pembiayaan al-qardh. Ketentuan Umum Al-qardh dalam bank syariah: 1) Al-qardh adalah pinjaman yang diberikan kepada nasabah (muqtaridh) yang memerlukan; 2) Nasabah al-qardh wajib mengemalikan jumlah pokok yang diterima pada waktu yang telah disepakati bersama; 3) Biaya administrasi dibebankan kepada nasabah; 4) LKS dapat meminta jaminan kepada nasabah bilamana dipandang perlu; 5) Nasabah al-qardh dapat memberikan tambahan (sumbangan) dengan sukarela kepada LKS delama tidak diperjanjikan dalam akad; 6) Jika nasabah tidak dapat mengembalikan sebagian atau seluruh kewajibannya pada saat yang telah disepakati dan LKS telah memastikan ketidakmampuannya, LKS dapat memperpanjang jangka waktu pengembalian atau menghapus (write off) sebagian atau seluruh kewajibannya. ${ }^{18}$

Dari ketentuan-ketentuan yang telah diatur tersebut, jika nasabah dalam hal ini tidak dapat mengembalikan atau terjadinya wanprestasi. LKS dapat memberikan sanksi kepada nasabah jika: 1) Ketika nasabah tidak menunjukkan keinginan mengembalikan sebagian atau seluruh kewajibannya dan bukan karena ketidakmampuannya, LKS dapat menjatuhkan sanksi kepada nasabah; 2) Sanksi yang dijatuhkan kepada nasabah sebagaimana dimaksud butir 1 dapat berupa dan tidak terbatas pada penjualan barang jaminan. Jika barang jaminan tidak mencukupi, nasabah tetap harus memenuhi kewajibannya secara penuh. ${ }^{19}$

Adapun yang menjadi sumber dana Al-qardh, sumber dana yang dapat digunkan oleh

16 Rachmadi Usman, Op.Cit, h. 245-246.

7 Santoso, Loc.Cit.

18 Fatwa Dewan Syariah Nasional Majelis Ulama Indonesia Nomor 19/DSN-MUI/IV/2001, tentang Alqardh.

19 Ketentuan umum dalam fatwa tentang al qardh juga diatur sama dalam Pasal 612 sampai Pasal 617 Kompilasi Hukum Ekonomi Syariah, Peraturan MahkamahAgung Nomor 2 Tahun 2008. 
bank syariah untuk akad Al-qardh dapat bersumber dari: a) Bagian modal LKS; b) Keuntungan LKS yang disisihkan; dan c) Lembaga lain atau individu yang mempercayakan penyaluran infaq-nya kepada $\mathrm{LKS}^{20}$

Fasilitas pembiayaan $\mathrm{Al}$-qardh bisa diberikan kepada mereka yang memerlukan pinjaman kepada para pengusaha mikro yang kekurangan dana, tetapi memiliki prospek bisnis yang sangat baik, masyarakat miskin yang memerlukan pinjaman lunak guna memperbaiki rumah, biaya sekolah anak, biaya pemasangan listrik, pembangunan sanitasi, pembangunan (water close), biaya persalinan, biaya berobat dan sebagainya, oleh karenanya Al-qardh sangat cocok apabila digunakan untuk program - program pengentasan kemiskinan dikarenakan pembiayaan $\mathrm{Al}$ qardh mempunyai fleksibilitas yang baik dalam penggunaanya serta berorientasi sosial. Dalam praktik perbankan Syariah, rukun dan syarat dalam akad Al-qardh selain diatas adalah: a) Bank (pihak yang menyediakan uang atau meminjamkan harta); b) Nasabah (pihak yang meminjam uang); c) Proyeksi usaha (tujuan dalam mengadakan perikatan al-qardh). ${ }^{21}$

Karena akad qardh adalah betuk dari akad tabarru', sehingga didalam penentuan syaratsyarat qardh ditentukan adanya kapabilitas dalam pelaksanaannya untuk melakukan akad qardh. Hal ini berarti dalam melakukan akad tersebut tidaklah mudah, diperlukan adanya syarat-syarat didalam menjalankannya.Pemberi maupun penerima pinjaman haruslah berakal sehat, bisa berlaku dewasa artinya cukup umur dalam melakukan tindakan hukum, baligh dikenal dalam Islam, dan berkendak tanpa ada paksaan.Syarat tersebut yang menjadi syarat untuk melakukan tabarru' (berderma), sehingga akad qardh merupakan akad dari akad tabarru'.

Terkait daripada syarat qardh tersebut, dapat kita simpulkan bahwa ada syarat-syarat subyek hukum didalam pelaksanaannya yakni, akad tersebut tidak boleh atau tidak dapat dilakukan oleh: orang gila, orang bodoh, anak kecil karena belum cukup umur dalam bertindak, orang yang dibatasi tindakannya dalam membelanjakan hartanya, orang yang dipaksa atau dalam keadaan terpaksa. Orang-orang tersebut yang merupakan orang yang tidak termasuk dalam syarat sahnya guna melakukan akad tabarru'.Oleh karena itu, syarat tersebut menjadi acuan untuk meminimalisir atau menghindari terjadinya suatu wanprestasi oleh para pihak yang menjalankan suatu perjanjian, agar dapat dipertangungjawabkan oleh para pihak dalam melakukan prestasi.

Sifat qardh ini tidak memberikan keuntungan finansial.Karena itu, pendanaan qardh dapat diambil menurut kategori. Pertama, akad Al-qardh yang diperlukan untuk membantu usaha sangat kecil dan keperluan sosial, dapat bersumber dari dana zakat, infaq, dan sedekah. Kedua, akad Al-qardh yang diperlukan untuk membantu keuangan nasabah secara cepat dan berjangka pendek. Talangan dana di atas dapat diambilakan dari modal bank.

Praktik Akad Al-qardh dalam Perbankan Syariah sebagai produk penyaluran dana yang bersifat pinjam meminjam ini biasanya diterapkan sebagai berikut: 1) Sebagai produk

\footnotetext{
$20 \quad$ Rachmadi Usman, Op.Cit., h. 249.

21 Muhammad Syafi'i Antonio, Op.Cit., h.134.
} 
pelengkap kepada nasabah yang telah terbukti loyalitas dan bonafiditasnya, yang membutuhkan dana talang segera untuk masa yang relatif pendek. Nasabah tersebut akan mengembalikannya secepatnya sejumlah uang yang dipinjamnya itu; 2) Sebagai fasilitas nasabah yang memerlukan dana cepat, sedangkan ia tidak bisa menarik dananya karena, misalnya, tersimpan dalam bentuk deposito; 3) Sebagai produk untuk menyumbangkan usaha yang sangat kecil atau membantu sektor sosial. Guna pemenuhan skema khusus ini telah dikenal suatu produk khusus, yaitu alqardhal-hasanah; 4) Sebagai dana talang untuk janga waktu singkat, maka nasabah akan mengembalikannya dengan cepat, seperti compensating balance dan factoring (anjak piutang). ${ }^{22}$

Pinjaman al-qardh biasanya diberikan oleh bank kepada nasabahnya sebagai fasilitas pinjaman talangan pada saat nasabah mengalami overdraft. Fasilitas ini dapat merupakan bagian dari satu paket pembiayaan lain, untuk memudahkan nasabah bertransaksi. Aplikasi al-qardh dalam perbankan ada empat hal: (a) Sebagai pinjaman talangan haji, (b) Sebagai pinjaman tunai dari produk kartu kredit syariah, (c) Sebagai pinjaman kepada pengusaha kecil, (d) Sebagai pinjaman kepada pengurus bank. Oleh karena itu, karakteristik-karakteristikyang dimiliki dari akad qardh tersebut menjadi ciri atau prinsip dari akad tabarru', sehingga akad qardh dikatakan sebagai akad tabarru'.

\section{Dasar Hukum Akad Pembiayaan Al-Qardh sebagai akad Tabarru'}

Sistem ekonomi syariah yang dalam penekanannya menerapkan konsep kemanfaatan yang dalam kegiatan ekonominya ditujuakan pada masyarakat yang lebih luas. Dimana suatu kegiatan tersebut manfaatnya bukan hanya pada akhir kegiatan akan tetapi juga pada proses transaksi dalam penyaluran dananya, yang harus selalu mengacu kepada konsep mementingkan kemaslahatan dan juga menjunjung tinggi asas keadilan. Selain daripada itu dalam bank syariah sebagai salah satu pelaku penggerak dalam kegiatan perekonomian yang menerapkan prinsip ekonomi Islam juga tidak lepas harus selalu menjunjung tinggi etika maupun moral hukum didalam kegiataanya.

Sebagai bentuk realisasi dari pada konsep syariah pada dasarnya perbankan syariah memiliki tiga ciri yang mendasar, yaitu (a) prinsip keadilan, (b) menghindari kegiatan yang dilarang, (c) memperhatikan aspek kemanfaatan. Selain tidak hanya memfokuskan untuk mengindari riba, ketiga ciri tersebut perlu diperhatikan sebagai sistem didalam perbankan syariah, sehingga tercipta sistem ekonomi yang seimbang.Maka dibentuklah aturan-aturan yang menjadi dasar hukum untuk mengatur sistem dalam operasional dunia perbankan, khususnya dalam perbankan syariah.

Pada transaksi pinjam meminjam bukan termasuk sebagai usaha pengembangan modal, akan tetapi hubungan bisnis dalam ajaran Islam tidak hanya didasari kepentingan semata, tetapi juga di dasari atas tolong menolong. Terkadang dalan bisnis tidak selalu untung bahkan merugi sehingga tidak menutup kemungkinan untuk berhutang untuk menutup kerugian tersebut.

22 Ibid, h. 133. 
Transaksi pinjam meminjam diperlukannya syarat dan ketentuan dalam bentuk akad untuk mengatur para pihak, karena kita ketahui bahwa di dalam penyaluran dana masayarakat oleh bank syariah tidak tertutup kemungkinan akan terjadinya resiko-resiko yang tidak diinginkan. Oleh karena itu, perlu diatur terkait dalam perjanjian hutang piutang tersebut, dimana hutang adalah wajib hukumnya untuk dibayar.

Terkait dengan pembiayaan Al-qardh ini ditetapkan mealui Surat Keputusan Direksi Bank Indonesia Nomor 32/34/Kep/Dir tentang Bank Umum Berdasarkan Prinsip Syariah, yang kemudian dipebaharui dengan Peraturan Bank Indonesia Nomor 6/24/PBI/2004 tentang Bank Umum yang Melaksanakan Kegiatan Usaha Berdasarkan Prinsip Syariah sebagaimana diubah dengan Peratuan Bank Indonesia Nomor 7/35/PBI/2005 dan Surat Keputusan Direksi Bank Indonesia Nomor 32/36/Kep/Dir tentang Bank Perkreditan Rakyat Berdasarkan Prinsip Syariah, yang kemudian diperbaharui dan disempurnakan dengan Peraturan Bank Indonesia Nomor 6/17/PBI/2004 tentang Bank Perkreditan Rakyat Berdasarkan Prinsip Syariah sebagaimana telah diubah dengan Peraturan Bank Indonesia Nomor 8/25/PBI/2006. Selanjutnya, dipertegas kembali sebagai kegiatan usaha perbankan syariah sebagaimana dalam Undang-Undang Nomor 21 Tahun 2008 tentang Perbankan Syariah (UU No. 21/2008).

Sebagaimana ketentuan dalam Pasal 1 angka 11 Peraturan Bank Indonesia Nomor 7/46/ PBI/2005 tentang Akad Penghimpunan dan Penyaluran Dana Bagi Bank yang Melaksanakan Kegiatan Usaha Berdasarkan Prinsip Syariah, diartikan Qardh, adalah pinjam meminjam dana tanpa imbalan dengan kewajiban pihak peminjam mengembalikan pokok pinjaman secara sekaligus atau cicilan dalam jangka waktu tertentu.

Demikian pula dalam penjelasan atau ketentuan Pasal 3 Peraturan Bank Indonesia Nomor 9/19/PBI/2007 tentang Pelaksanaan Prinsip Syariah Dalam Kegiatan Penghimpun Dana dan Penyaluran Dana Serta Pelayanan Jasa Bank Syariah, memberikan pengertian yang sama bahwa yang dimakud dengan Qardh adalah transaksi pinjam meminjam dana tanpa imbalan dengan kewajiban pihak peminjam mengembalikan pokok pinjaman secara sekaligus atau cicilan dalam jangka waktu tertentu. Penjelasan yang sama juga dapat dijumpai dalam Penjelasan Pasal 19 ayat (1) huruf e UU No. 21/2008, bahwa yang dimkasud dengan 'akad qardh' adalah akad pinjaman dana kepada nasabah dengan ketentuan bahwa nasabah wajib mengembalikan dana yang diterimanya pada waktu yang disepakati.

Pembiayaan Al-qardh merupakan produk layanan pembiayaan perbankan syariah yang diperbolehkan, dimana sah adanya dan tidak bertentangan dengan syariah. Eksistensi pembiayaan Al-qardh tersebut mempunyai landasan syariah yang mengacu pada dalil-dalil dalam hukum Islam yang bersumber pada Al-Quran dan hadits, yaitu:23 1) Q.S. Al-Baqarah (2):282, yang menyatakan "Hai orang-orang yang beriman apabila kamu bermuamalahh tidak secara tunai sampai pada waktu tertentu, buatlah secara tertulis"; 1) Q.S. Al-Baqarah (2):245 yang menyatakan "Siapakah yang mau member pinjaman kepada Allah, pinjaman yang baik

23 Rachmadi Usman, Op.Cit., h. 247. 
(menafkahkan hartanya di jalan Allah), maka Allah akan memperlipatgandakan pembayaran keadanya dengan lipat ganda yang banyak.Dana Allah menyempitkan dan melapangkan (rezeki) dan kepada-Nya-lah kamu dikembalikan"; 3) Q.S. Al-Hadid (57):11 yang menyatakan "Siapakah yang mau meminjamkan kepada Allah pinjama yang baik, maka Allah akan melipatgandakan (balasan) pinjaman itu untuknya, dan dia akan memperoleh pahala yang banyak"; 4) Q.S. AlMuzzammil (73):20 yang menyatakan "Dirikanlah shalat, tunaikanlah zakat, dan berikanlah pinjaman kepada Allah pinjaman yang baik (qardhul hasan). Dan kebaikan apa saja yang kamu perbuat untuk dirimu nisccaya kamu memperoleh (balasan)nya di sisi Allah sebagai balasan yang paling baik dan yang paling besar pahalanya." serta Hadis Riwayat Muslim dari Abu Hurairah r.a. Bahwa Rasulullah Saw telah bersabda "Orang yang melepaskan seorang Muslim dari kesulitan di dunia, Allah akan melepaskan kesulitanya di hari kiamat; dan Allah senantiasa menolong hamba-Nya selama ia (suka) menolong saudaranya."

Sebagai dasar hukum selanjutnya dari akad al-qardh ini, penetapan para ulama juga telah menyepakati bahwa akad al-qardh boleh dilakukan.Kesepakatan ulama ini didasari tabiat manusia yang tidak bisa hidup tanpa pertolongan dan bantuan saudaranya. Tidak ada seorangpun yang memiliki segala barang yang ia butuhkaan. Oleh karena itu, pinjam-meminjam sudah menjadi satu bagian dari kehidupan di dunia ini.Islam adalah agama yang sangat memperhatikan segenap kebutuhan umatnya". ${ }^{24}$

Kemudian para fuqaha mendefinisikan Ariah sebagai pembolehan oleh pemilik akan miliknya untuk dimanfaatkan oleh orang lain dengan tanpa ganti kerugian (imbalan). Untuk Ariah disyaratkan tiga hal sebagai berikut: a) Bahwa orang yang meminjamkan adalah pemilik yang berhak untuk menyerahkannya; b) Bahwa materai yang dipinjamkan dapat dimanfaatkan; c) Bahwa pemanfaatan itu dibolehkan..$^{25}$

Selain itu juga dalam rangka berperan sebagai lembaga sosial, di samping lembaga komersial, LKS pun dapat melakukan penyaluran dana melalui pinjaman al-qardh, Dewan Syariah Nasional telah menetapkan fatwa tentang akad ini sebagai pedoman LKS, termasuk Perbankan Syariah sebagaimana tersebut dalam Fatwa DSN Nomor 19/DSN-MUI/IV/2001 tentanng Al-Qardh, adapun dalil-dalil sebagai landasan filosofis dalam penetapan fatwa tersebut yaitu:

1. Firman Allah SWT, antara lain:

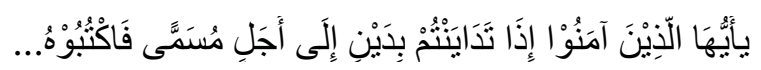

«Hai orang yang beriman! Jika kamu bermu>amalah tidak secara tunai sampai waktu tertentu, buatlah secara tertulis...» (QS. al-Baqarah (2): 282).

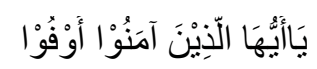

“Hai orang yang beriman!Penuhilah akad-akad itu”.(QS. al-Maidah (5): 1).

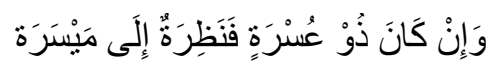

24 Muhammad Syafi'i Antonio, Op.Cit., h.132.

25 Trisadini P. Usanti, A. Shomad, Op.cit., h. 35. 
"Dan jika ia (orang yang berhutang itu) dalam kesulitan, berilah tangguh sampai ia berkelapangan”.(QS. al-Baqarah (2): 280).

2. Hadis-hadis Nabi s.a.w., antara lain:

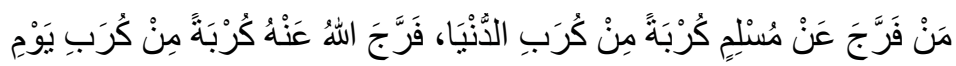

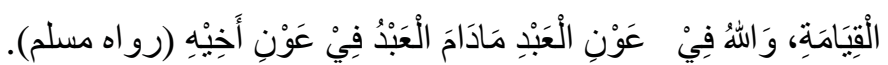

"Orang yang melepaskan seorang muslım aarı kesulıtannya al dunıa, Allan akan melepaskan kesulitannya di hari kiamat; dan Allah senantiasa menolong hamba-Nya selama ia (suka) menolong saudaranya". (HR. Muslim).

$$
\text { مَطْلُ الَغَنِيِّ ظَلْمُ (رواه الجماعة) }
$$

"Penundaan (pembayaran) yang dilakukan oleh orang mampu adalah suatu kezaliman”. (HR.

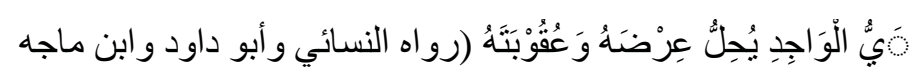

"Penundaan (pembayaran) yang dilakukan oleh orang mampu menghalalkan harga diri dan memberikan sanksi kepadanya”. (HR. Nasa'i, Abu Daud, Ibn Majah, dan Ahmad).

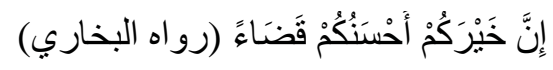

"Orang yang terbaik di antara kamu adalah orang yang paling baik dalam pembayaran hutangnya”. (HR. Bukhari).

3. Hadis Nabi riwayat Tirmidzi dari Amr bin Auf:

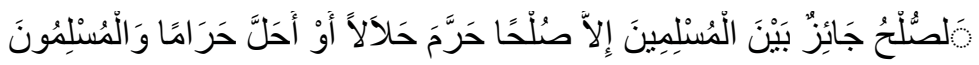

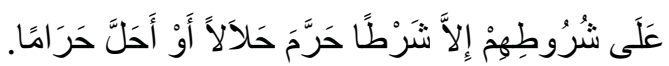

"Perdamaian dapat dilakukan di antara kaum muslimin kecuali perdamaian yang mengharamkan yang halal atau menghalalkan yang haram; dan kaum muslimin terikat dengan syarat-syarat mereka kecuali syarat yang mengharamkan yang halal atau menghalalkan yang haram”.

4. Kaidah fiqih

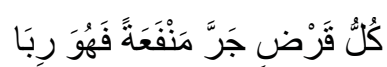

"Setıap utang plutang yang menaatangkan manjaat (bagl yang berpiutang, muqrian) adalah riba".

\section{Kesimpulan}

Dalam pelaksanaan operasional sistem perbankan syariah akan tercermin prinsip ekonomi syariah dalam bentuk nilai-nilai yang secara umum dapat dibagi dalam dua perspektif, yaitu mikro dan makro. Nilai mikro menekankan aspek kompetensi/profesionalisme dan sikap amanah, sedangkan dalam perspektif makro nilai-nilai syariah menekankan aspek distribusi, pelarangan riba dan kegiatan ekonomi yang tidak memberikan manfaat secara nyata kepada 
sistem perekonomian. ${ }^{26}$ Sehingga manfaat dari sistem dalam perbankan syariah ini tidak hanya ditujukan kepada masyarakat yang beragama Islam, tetapi ditujukan dan dapat dirasakan oleh seluruh umat manusia (rahmatan lil 'alamin).

Berdasakan urain tersebut diatas dapat disimpulkan bahwa, akad qardh merupakan salah satu dari akad tabarru' dimana karakteristik daripada akad qardh tersebut adalah akad pinjam meminjam yang menitikberatkan pada sikap tolong menolong atau ta'awun dan juga jenis akad qardh yang tidak mengambil keuntungan atau transaksi non profit. Dalam akad qardh yang merupakan akad tabarru' meskipun hanya menetapkan di awal Rp.100,- itu tetap haram dalam syariah, bukan hanya karena ditetapkan di awal, tetapi kapan saja bila dimina oleh kreditor (bukan inisiatif debitor) itu tetap riba (tambahan) dan tidak diperbolehkan. Dalam praktiknya perbankan syariah ada dikenal namanya biaya, jadi tambahan untuk biaya sepeti biaya administrasi, biaya materai, ini diperbolehkan. Menurut istilah para ahli fikih, al qardh adalah memberikan suatu harta kepada orang lain untuk dikembalikan tanpa ada tambahan. $A l$ Qardh(pinjam meminjam) hukumnya boleh dan dibenarkan secara syariat.Tidak ada perbedaan pendapat di antara para ulama dalam hal ini.

\section{Daftar Bacaan}

Anshori,Abdul Ghofur GadaiSyariahDiIndonesia: Konsep, Implementasi dan Institusionalisasi, Yogjakarta: Gadjah Mada University Press, 2006.

Basyir, Abu Umar Fikih Ekonomi Keuangan Islam, Jakarta: Darul Haq, 2008.

Departemen Agama RI., Al-Qur'an dan Terjemahnya, Semarang: Kumudaskoro Grafindo, 1994.

Ghafur, Fakhri,Buku Pintar Transaksi Syariah, Jakarta: Mizan Publika, 2010.

Mujieb, M. Abdul et.al.,Kamus Istilah fiqh, CetakanPertama, Jakarta:Pustaka Firdaus, 1994.

Shomad,Abd.dan Trisadini P.Usanti, "Asas-Asas Perikatan Islam dalam Akad Pembiayaan”Yuridika, Volume 24, No.3. September-Desember, 2009.

Sula, Muhammad Syakir Asuransi Syari'ah (Life and General): Konsep dan system Operasional, Cetakan Pertama, Jakarta: Gema Insani Press, 2004. 

$\mathrm{A}$

accountability 361

agency agreement 361

agrarian reform 147

akad 406

ASEAN 73, 74

authority 169

authority of PPATK 314

B

badan hukum 331

bangun guna serah 59

banking 13

bankruptcy 43

build operate transfer 59

building right title 59

C

camat 189

central government 169

combating money laundering 314

concurrent governmental affair 169

constitutional court 211

construction contract in indonesia 385

construction services company 385

copyrights 351

corporate criminal responsibility 331

corporate shares 73

counterfeit 351

cukai 169

dana bagi hasil 169

$\mathrm{D}$

delegation 189

demokrasi 91

distributor 361

E

efek 43

exclusive rights 351

$\mathrm{F}$

freehold title 59

G

government 293, 304

$\mathrm{H}$

hak asasi manusia 293 hak cipta 351

hak ekslusif 351

hak guna bangunan 59

hak kebendaan 117

hak milik 59

hak pengelolaan 59

hak tanggungan 117

harmonisasi hukum 74

hasil tembakau 169

head of district 189

human rights 293

human rights court 211

I

illegal 1

imigran 1

Indonesia 1

$\mathrm{J}$

jaminan 117

judicial review 211

K

kedaulatan 1

kepailitan 43

kewenangan pemerintah pusat 169

kewenangan pemerintahan provinsi 169

kewenangan ppatk 314

kontrak konstruksi di indonesia 385

$\mathrm{L}$

land-reform 147

legal entity 331

legal harmonization 73

legislative drafting 304

local authorities 304

local legislative 304

M

Mahkamah Konstitusi 211

mediasi 13

mediation 13

migrant. 1

N

negara 1

negara hukum 293

non-badan hukum 331

non-legal entity 331 
$\mathrm{O}$

operational rights 59

$\mathrm{P}$

pajak 28

parliamentary threshold 91

partai politik 91

pasar tunggal 74

pembajakan 351

pemerintah 293, 304

pemerintah daerah 304

pemerintahan daerah 189

penanggulangan pencucian uang 314

pendelegasian wewenang 189

pengujian undang-undang 211

penyelenggaraan jasa konstruksi 385

peradilan pajak 28

perancangan undang-undang 304

peraturan daerah 304

perbankan 13

perjanjian keagenan 361

principal 361

profit-sharing 169

provincial government. 169

Q

qardh 406

$\mathrm{R}$

reformasi agrarian 147

regional government 189

right in rem 117 right of ownership 59

risiko 13

risk 13

rule of law 293

$\mathrm{S}$

saham perusahaan 74

satuan rumah susun 59

securities 43

security interest 117

sengketa pajak 28

short selling 43

short selling 43

single market 73

sovereignty 1

stakeholders 147

stakeholders 147

state 1

strata title 59

$\mathrm{T}$

tabarru'. 406

tanggung gugat 361

tanggung jawab kejahatan korporasi 331

$\operatorname{tax} 28$

tax court 28

tax dispute 28

tobacco-product duty 169

$\mathrm{U}$

urusan pemerintahan 169 